(2)

\title{
Identification of priorities for multidisciplinary intersectoral research on violence against older women
}

This article was published in the following Dove Medical Press journal: Journal of Multidisciplinary Healthcare

\author{
Sarah D Kosa ${ }^{1,2}$ \\ Sheila Macdonald' \\ Maureen Etkin ${ }^{3}$ \\ Raeann Rideout ${ }^{3}$ \\ Janice Du Mont ${ }^{2,4}$ \\ 'Ontario Network of Sexual Assault/ \\ Domestic Violence Treatments \\ Centres, Toronto, ON, Canada; \\ ${ }^{2}$ Women's College Research Institute, \\ Women's College Hospital, Toronto, \\ ON, Canada; ${ }^{3}$ Elder Abuse Ontario, \\ Etobicoke, ON, Canada; ${ }^{4}$ Dalla Lana \\ School of Public Health, University of \\ Toronto, Toronto, ON, Canada
}

Correspondence: Janice Du Mont; Sarah D Kosa

Women's College Research Institute, Women's College Hospital, 76 Grenville St, Toronto, ON M5S IB2, Canada

Tel + I 4163513732

Fax +I 4163237518

Email janice.dumont@wchospital.ca; sarahdaisy.kosa@wchospital.ca

\section{Introduction}

It has been acknowledged globally and in Canada that to address the growing and significant health and social problem of violence against older women, it is essential that key stakeholders work collaboratively across sectors and disciplines to identify research priorities, as well as methodological approaches and potential challenges to consider in moving these priorities forward..$^{1-3}$ To this end, we engaged leaders of professional health care associations, managers of health, social, and community services, government policymakers, and researchers in a two-step Delphi consensus process in Canada's largest province, Ontario. ${ }^{46}$

\section{Round I online survey}

An online survey was developed that included sex, age, affiliation, and perceived level of expertise with respect to violence against older women. It also contained instructions to write-in and rank from most to least important up to six research priorities that would advance knowledge, practice, and policy in the field.

The online survey was emailed to key stakeholders in Ontario invited to attend a 1-day forum featuring international and Canadian experts speaking about violence against older women (https://www.sadvtreatmentcentres.ca/violence-against-olderwomen.html). These experts were also invited to complete the survey. Two reminders were sent subsequently over a 1-month period. Forty-four (36\%) of the 121 invitees completed the survey. The priorities were then collated thematically by the researchers, and a weighted score was calculated for each priority (weighted score $=$ number of first rankings $\times 6+$ number of second rankings $\times 5 \ldots$ number of sixth rankings $\times 1$ ). The five priorities with the highest scores were retained for the next round.

\section{Round 2 in-person meeting}

A paper-based survey was created from the online survey with instructions to re-rank the five research priorities retained from the first round. The survey was administered to a smaller group of forum attendees identified as having expertise in violence against women and/or elder abuse in a 1.5 -hour in-person meeting held immediately following the forum. In advance of the distribution of the survey, the top five research priorities from Round 1 were presented alphabetically. All 21 (100\%) participants in the meeting completed a survey. These surveys were then collected and weighted scores were 
immediately calculated for each priority (weighted score $=$ number of first rankings $\times 5+$ number of second rankings $\times 4 \ldots$ number of fifth rankings $\times 1$ ) and shared with all participants.

To identify methodological approaches and potential challenges in addressing the top research priorities, each of five trained facilitators led a brainstorming session on a pre-assigned priority with the participants who had been evenly distributed across tables by discipline and expertise. The researchers limited the number of participants in this meeting to allow for active discussion. Each facilitator shared the results of their session with the full group of participants. These findings were then immediately further synthesized based on feedback.

\section{Participants}

Most of the 44 participants in Round 1 and 21 participants in Round 2 rated their own expertise in violence against older women highly (see Table 1 for participant characteristics including sex, affiliation, country, and level of expertise).

\section{Research priorities}

In the first round, the highest ranked research priories were: examination of contextual and contributing factors; development and evaluation of interventions/best practices for care; development and evaluation of knowledge mobilization initiatives including education, training, and resources for diverse audiences; evaluation of currently available services; and examination of different types of violence and abuse. Lower ranked priorities included: analysis of legal and legislative issues; examination of theoretical frameworks and approaches; investigation of access to care issues including barriers to seeking help; assessment of needs of diverse abused older women; examination of research methods for data collection on violence against older women; identification/screening for violence and abuse; examination of resource utilization; and determination of the prevalence and nature of violence against older women.

After the second round of ranking, the top five research priorities were: development and evaluation of interventions/ promising practices for care; development and evaluation of knowledge mobilization including education, training, and resources for diverse audiences; examination of contextual and contributing factors; evaluation of currently available services; and examination of different types of violence and abuse (Table 2).
Table I Participant characteristics of Delphi consensus survey Round I and Round 2

\begin{tabular}{|c|c|c|c|c|}
\hline \multirow[t]{2}{*}{ Characteristic } & \multicolumn{2}{|c|}{ Round I } & \multicolumn{2}{|c|}{ Round 2} \\
\hline & $\%$ & $n$ & $\%$ & $\mathrm{n}$ \\
\hline Sex/gender & & 44 & & 21 \\
\hline Female & 97.7 & 43 & 90.5 & 19 \\
\hline Male & 2.3 & 1 & 4.8 & 1 \\
\hline Transgender & & & 4.8 & 1 \\
\hline Affiliation $^{a}$ & & 44 & & 21 \\
\hline University/academia & 15.9 & 7 & 52.4 & II \\
\hline Hospital/clinic & 13.6 & 6 & 4.8 & 1 \\
\hline Community organization (eg, social service) & 45.5 & 20 & 23.8 & 5 \\
\hline Policy/government & 11.4 & 5 & 14.3 & 3 \\
\hline Student/trainee & 4.6 & 2 & & \\
\hline Other $^{b}$ & 11.4 & 5 & 4.8 & 1 \\
\hline Country & & 44 & & 21 \\
\hline Canada & 88.6 & 39 & 81.0 & 17 \\
\hline Ontario & & 37 & & 15 \\
\hline British Columbia & & 2 & & 2 \\
\hline USA & 6.8 & 3 & 14.3 & 3 \\
\hline UK & 2.3 & I & & \\
\hline Australia & 2.3 & 1 & 4.8 & 1 \\
\hline $\begin{array}{l}\text { Level of expertise about violence } \\
\text { against older women }\end{array}$ & & 44 & & 21 \\
\hline Very high & 25.0 & II & 28.6 & 6 \\
\hline High & 38.6 & 17 & 52.4 & II \\
\hline Medium & 29.6 & 13 & 19.1 & 4 \\
\hline Low & 6.8 & 3 & 0.0 & 0 \\
\hline Very low & 0.0 & 0 & 0.0 & 0 \\
\hline
\end{tabular}

Notes: ${ }^{a}$ Categories are not mutually exclusive. 'Includes professional nursing association, law enforcement services, funding organization, and feminist advocacy organization.

\section{Methodological approaches and potential challenges}

Participants recommended a diverse range of methodological approaches to address the identified research priorities, from randomized control trials for the development and evaluation of interventions to "getting women's voices" using interviews of those with lived experiences for the examination of contextual and contributing factors. Many potential challenges in conducting this research were also identified, including the lack of standardized measures and selection of key outcomes (Table 2).

\section{Conclusion}

It is important when interpreting this study's findings to consider that the results represent the opinions of participants 
Table 2 Priorities, methodological approaches, and potential challenges for future research on violence against older women

\begin{tabular}{|c|c|c|c|}
\hline Priority $^{a}$ & Rank & Methodological approach & Potential challenge \\
\hline $\begin{array}{l}\text { Development } \\
\text { and evaluation } \\
\text { of interventions/ } \\
\text { promising practices } \\
\text { for care }\end{array}$ & $\begin{array}{l}\text { No. of } 1 \mathrm{st}=10 \\
\text { No. of } 2 \mathrm{nd}=4 \\
\text { No. of } 3 \mathrm{rd}=1 \\
\text { No. of } 4 \mathrm{th}=4 \\
\text { No. of } 5 \mathrm{th}=2 \\
\text { Weighted score }=79\end{array}$ & $\begin{array}{l}\text { - Randomized control trials that are designed } \\
\text { to capture cost-benefit by capturing resource } \\
\text { utilization and quality of life/utility } \\
\text { - Mixed methods research which employs qualitative } \\
\text { interviews in the initial steps of a project, the } \\
\text { findings of which subsequently could inform } \\
\text { quantitative data collection } \\
\text { - Use of language of "promising practices" as opposed } \\
\text { to "best practices" when developing interventions }\end{array}$ & $\begin{array}{l}\text { - Consideration of contextual factors } \\
\text { - Inclusion of multiple types of abuse } \\
\text { - Lack of standardized measures for } \\
\text { the population under study } \\
\text { - Selection of outcomes that different } \\
\text { funding sectors can buy into/ } \\
\text { understand and show social return } \\
\text { on investment }\end{array}$ \\
\hline $\begin{array}{l}\text { Development } \\
\text { and evaluation } \\
\text { of knowledge } \\
\text { mobilization initiatives } \\
\text { including education, } \\
\text { training, and resources } \\
\text { for diverse audiences }\end{array}$ & $\begin{array}{l}\text { No. of Ist=7 } \\
\text { No. of } 2 \mathrm{nd}=3 \\
\text { No. of } 3 \mathrm{rd}=4 \\
\text { No. of } 4 \mathrm{th}=3 \\
\text { No. of } 5 \mathrm{th}=4 \\
\text { Weighted score }=69\end{array}$ & $\begin{array}{l}\text { - Intersectional framework that considers the different } \\
\text { social locations of and forms of discrimination faced } \\
\text { by older women experiencing violence } \\
\text { - Engagement of universities and community agencies } \\
\text { in developing stand-alone courses and integrated } \\
\text { content on violence against older women for } \\
\text { students, service providers, and the public }\end{array}$ & $\begin{array}{l}\text { - Lack of standardized measures } \\
\text { to evaluate success of knowledge } \\
\text { mobilization initiatives } \\
\text { - Difficulty in working across sectors } \\
\text { - Pervasiveness of "gender neutrality" }\end{array}$ \\
\hline $\begin{array}{l}\text { Examination of } \\
\text { contextual and } \\
\text { contributing factors }\end{array}$ & $\begin{array}{l}\text { No. of Ist=2 } \\
\text { No. of } 2 \mathrm{nd}=5 \\
\text { No. of } 3 \mathrm{rd}=9 \\
\text { No. of } 4 \mathrm{th}=5 \\
\text { No. of } 5 \text { th }=0 \\
\text { Weighted score }=67\end{array}$ & $\begin{array}{l}\text { - "Getting women's voices" using interviews of those } \\
\text { - Pith diverse lived experience } \\
\text { - Inclusion of organizations that older women } \\
\text { participate in/reside at } \\
\text { - Inclusion of debriefing and support for participants } \\
\text { - Use of passive, non-pressured recruitment strategies } \\
\text { - Collaboration with health authorities, long-term } \\
\text { care facilities, community organizations, immigration } \\
\text { services, and other organizations that can help } \\
\text { understand relational and structural issues }\end{array}$ & $\begin{array}{l}\text { - Clear and consist definition of factors } \\
\text { - Recruitment of representative } \\
\text { samples that include older women } \\
\text { with diminished capacity } \\
\text { - Overcoming obstacles associated } \\
\text { with the informed consent process to } \\
\text { ensure "no voices are lost" } \\
\text { - Ensuring the availability of translation } \\
\text { services }\end{array}$ \\
\hline $\begin{array}{l}\text { Evaluation of currently } \\
\text { available services }\end{array}$ & $\begin{array}{l}\text { No. of Ist=0 } \\
\text { No. of } 2 \mathrm{nd}=6 \\
\text { No. of } 3 \mathrm{rd}=7 \\
\text { No. of } 4 \mathrm{th}=4 \\
\text { No. of } 5 \text { th }=4 \\
\text { Weighted score }=57\end{array}$ & $\begin{array}{l}\text { - Mixed methods design assessing: } \\
\text { I. Access to and quality of care including language } \\
\text { and transportation barriers } \\
\text { 2. Issues related to capacity to consent } \\
\text { 3. Policies around visitation of abusive partners in } \\
\text { long-term care } \\
\text { 4. Services for abusers } \\
\text { - Use of outcome measures inclusive of diverse } \\
\text { groups of older women }\end{array}$ & $\begin{array}{l}\text { - Difficulty in engaging community } \\
\text { in the development of appropriate } \\
\text { manuals and protocols to guide } \\
\text { evaluations } \\
\text { - Recruitment, in particular, the } \\
\text { engagement of abusers }\end{array}$ \\
\hline $\begin{array}{l}\text { Examination of } \\
\text { different types of } \\
\text { violence and abuse }\end{array}$ & $\begin{array}{l}\text { No. of } I s t=2 \\
\text { No. of } 2 \mathrm{nd}=3 \\
\text { No. of } 3 \mathrm{rd}=0 \\
\text { No. of } 4 \mathrm{th}=5 \\
\text { No. of } 5 \text { th }=11 \\
\text { Weighted score }=43\end{array}$ & $\begin{array}{l}\text { - Interviews and surveys of older women and men as } \\
\text { well as their providers }\end{array}$ & $\begin{array}{l}\text { - Capturing the different topologies of } \\
\text { domestic violence in the context of } \\
\text { intimate relationships among older } \\
\text { adults }\end{array}$ \\
\hline
\end{tabular}

Note: alisted from highest to lowest rank.

and, therefore, a differently composed sample may have generated different priorities. The top-ranked research priority for addressing violence against older women was the development and evaluation of interventions/promising practices for care using rigorous methodological approaches such as randomized control trials designed to capture a comprehensive range of outcomes that can demonstrate social return on investment. The higher rank of this priority likely reflects the paucity of intervention-based research as compared to other types of research in this field. The five priorities identified in this study and the methods proposed to address them represent an important first step in carrying out collaborative and multidisciplinary research focused on preventing and addressing the occurrence and harmful health and social consequences of the victimization of older women. 


\section{Ethics statement}

The study was reviewed by the Women's College Hospital Research Ethics Office and was granted an exemption (administrative review: REB No. 2017-0072-E).

\section{Acknowledgments}

This project was funded by the Social Sciences and Humanities Research Council of Canada (Grant No. 611-2016-0464). We would like to thank all the participants in this research and Marni Wolf, Rebecca Abavi, Susannah Ireland, Rebecca Yang, Stephanie Lanthier, Natalie Hope, and Shirley Solomon for their assistance with this project.

\section{Disclosure}

The authors report no conflicts of interest in this work.

\section{References}

1. Brownell P. Neglect, abuse and violence against older women: definitions and research frameworks. SEEJPH. 2014;1:1-12.

Journal of Multidisciplinary Healthcare

\section{Publish your work in this journal}

The Journal of Multidisciplinary Healthcare is an international, peerreviewed open-access journal that aims to represent and publish research in healthcare areas delivered by practitioners of different disciplines. This includes studies and reviews conducted by multidisciplinary teams as well as research which evaluates the results or conduct of such teams or health
2. James K, Dickinson R, Struthers A. Older women fleeing violence and abuse in Canada: bringing together separate spheres of practice. J Elder Abuse Negl. 2015;27(4-5):454-469.

3. United Nations, Department of Economic and Social Affairs. World population ageing. New York, NY: United Nations, Department of Economic and Social Affairs [updated 2013; cited 2018 November 13]. Available from: http://www.un.org/en/development/desa/population/ publications/pdf/ageing/WPA2015_Report.pdf. Accessed November 14, 2018.

4. Hyman I, Vahabi M, Bailey A, et al. Taking action on violence through research, policy, and practice. Glob Health Res Policy. 2016;1(1):1-9.

5. Mcdonald L, Hitzig SL, Pillemer KA, et al. Developing a research agenda on resident-to-resident aggression: recommendations from a consensus Conference. J Elder Abuse Negl. 2015;27(2):146-167.

6. Sivananthan SN, Chambers LW. A method for identifying research priorities for health systems research on health and aging. Healthc Manage Forum. 2013;26(1):33-36.

7. Weeks L, Dupuis-Blanchard S, Arseneault R, Macquarrie C, Gagnon D, Leblanc GM. Exploring gender and elder abuse from the perspective of professionals. J Elder Abuse Negl. 2018;30(2):127-143. care processes in general. The journal covers a very wide range of areas and welcomes submissions from practitioners at all levels, from all over the world. The manuscript management system is completely online and includes a very quick and fair peer-review system. Visit http://www.dovepress.com/ testimonials.php to read real quotes from published authors. 